\title{
The Confirmation Obstacle Course: Signaling Opposition through Delay
}

\author{
Lisa M. Holmes, Salmon A. Shomade, and Roger E. Hartley
}

We examine the time required for lower federal court nominees to complete the confirmation process. Using proportional hazards models, we analyze delay at the Judiciary Committee stage and the full Senate vote stage from 1977 to 2010, finding that delay has been used by members of the committee and the full Senate to signal opposition to nominees. Delay at the committee stage has influenced delay on the Senate floor for circuit and district court nominees, at least in the years since Robert Bork's failed nomination to the U.S. Supreme Court. Our findings indicate that senators pick up on committee delay as a cue in the confirmation process. Examining the distinct stages of the confirmation process provides important new insights into legislative signaling behavior and confirmation politics.

In January of 2007, three long-standing nominations to the U.S. Courts of Appeals came to an end when William Haynes, William Myers III, and Terrence Boyle were withdrawn from consideration. Although their withdrawals were motivated by the Democratic takeover of the U.S. Senate, these individuals had been languishing in the judicial appointment process for years, beginning in 2001 for Boyle and 2003 for Haynes and Myers. The experiences of these three nominees demonstrate that in the modern confirmation process "delays are used not only to provide senators more time to consider nominees but to force nominees to withdraw before being confirmed" (Bell 2002a, 46).

The use of delay tactics in the Senate as a means of obstructing a president's nominees is well documented in the scholarly literature (see Bell 2002a, 2002b; Goldman 2003; Goldman et al. 2011; Hartley and Holmes 2002; and Scherer 2005, among others). ${ }^{1}$ However, less is understood about how delay is utilized at various stages in the confirmation process. The confirmation obstruction faced by Boyle, Haynes, and Myers came at both the Judiciary Committee stage (in holding hearings and reporting the

The authors would like to thank the anonymous reviewers and ARP editor Andrew Dowdle for their thoughtful comments, Richard W. Frank and Alan Howard for their advice on proportional hazards models, and Sheldon Goldman and Amy Steigerwalt for their generosity in sharing data for this project.

Lisa M. Holmes is Associate Professor of Political Science at the University of Vermont. Salmon A. Shomade is an Assistant Professor of Political Science and the Pre-law Advisor at the University of New Orleans. Roger E. Hartley is Associate Professor and Director of the Master of Public Affairs program at Western Carolina University.

The American Review of Politics, Vol. 33, Spring, 2012: 23-49

(c)2012 The American Review of Politics 
nominations out of committee), and at the full Senate stage as each waited for a confirmation vote subsequent to being reported out of committee. Goldman $(2003,252)$ has labeled the contemporary lower court confirmation process "an obstacle course for some nominees" given that delay can stymie a nominee at any stage of the confirmation process, and quick confirmation by the full Senate is no longer "a routine process" after a nominee is reported out of committee.

In this study, we examine the delay associated with the "obstacle course" of the circuit and district court confirmation process, using duration models to examine delay at the committee stage and the full Senate vote stage to determine when delay is utilized by those involved in the two distinct phases of the confirmation process. In doing so, we get a better understanding of when delay is utilized at each distinct phase of the confirmation process, and as well are able to examine how the committee and the full Senate interact when it comes to exercising their important confirmation powers. We are also interested in examining how confirmation politics since the late 1980s (subsequent to the highly contention nomination of Robert Bork to the U.S. Supreme Court) have differed from that of the preceding decade, when confirmation politics were becoming more salient but were not yet fully affected by interest group involvement or partisan contention. We rely on signaling theory to understand how delay in the confirmation process can be used not only to defeat nominees, but to act as an independent cue to others members of the Senate and to interested groups.

\section{Obstruction and Delay in the Lower Court Confirmation Process}

Previous research on judicial appointment politics points to a dramatic increase in the politicization of the confirmation process in recent years, with partisan and electoral politics playing a central role in confirmation obstruction and delay. Many studies of the modern lower court confirmation process point to the Carter administration as an important turning point given Carter's attempt to wrest some control away from home-state senators in order to further his interests in diversity and merit selection (Allison 1996; Goldman 1997; Hartley and Holmes 1997, 2002). As such, the late 1970s represents the start of the modern lower court appointment era, and many studies of modern judicial appointment politics begin their analyses in the late 1970s (Bell 2002b; Martinek et al. 2002; Massie et al. 2004; Solowiej et al. 2005).

Subsequent to the Carter administration, lower court appointments have become increasingly politicized and contentious. Martinek et al. (2002) found that circuit court nominees made after the failed nomination of Robert 
Bork to the U.S. Supreme Court experienced more delay than did earlier nominations. In addition, in developing an index of obstruction and delay, Goldman (2003) found that conflict in the confirmation process initially spiked in the 100th Congress, coinciding with the Bork nomination. In their analysis of the Supreme Court confirmation process, Epstein et al. (2006) as well found that the Bork nomination triggered a new era of increased politicization in senatorial treatment of nominees. Thus, the Bork nomination in 1987 distinguishes two eras within the modern judicial confirmation process. In the pre-Bork era, judicial appointment politics were affected by institutional reform and heightened political interest, highlighted by reforms such as President Carter's creation of the United States Circuit Judge Nominating Commission and President Reagan's request that Republican senators submit more options for the president to fill vacancies on the district courts (Goldman 1997). Subsequent to the Bork nomination, however, confirmation politics have become associated with increased delay and fully concerted interest group engagement (Bell 2002a; Scherer 2005; Slotnick and Goldman 1998).

Most studies of confirmation delay focus on the length of time required for a nominee to proceed from referral to Senate confirmation (or defeat). However, two descriptive analyses have focused on delay in the distinct phases of the confirmation process. Slotnick and Goldman (1998) found that the bulk of the delay seen in the confirmation process occurred prior to the initiation of hearings before the Judiciary Committee. They found that confirmation tended to occur fairly quickly once hearings were held, but did note that election year politicking in 1995 and 1996 (when Senate Majority Leader Bob Dole was running against President Clinton) served to lengthen the time the average nominee had to wait for a floor vote. Goldman (2003) found that increased delay at the Senate vote stage transcended the specific electoral context of the 1996 presidential election. Starting with the 104th Congress, lengthier delays were experienced by district and circuit court nominees even after the committee had finished its work.

Basinger and Mak (2010) have as well noted that confirmation delay can occur at the two distinct phases in the confirmation process, and that partisan politics and obstructionist tactics may operate differently in the two phases. However, in their assessment of confirmation delay, Basinger and Mak did not take advantage of examining delay at the committee stage separately from delay at the full Senate stage. Similarly, Slotnick and Goldman (1998) and Goldman (2003) did not assess systematically what factors influenced delay at each distinct stage. Their analyses are nonetheless helpful in prompting us to consider three things. First, although the nominee's treatment by the Senate Judiciary Committee is often the key determinant of 
delay in the overall confirmation process, delay experienced at the hands of the full Senate has increased in recent years. Bell (2002a) and Scherer (2005) argue that all senators have become more interested in utilizing lower court confirmation politics to make public appeals to particularly interested activists, resulting in more obstructionist behavior at the vote stage of the confirmation process. Second, what may influence treatment of a nominee by the committee may be different from what influences delay at the hands of the full Senate. During much of the George W. Bush administration, the distinction between Judiciary Committee and full Senate treatment of nominees was exemplified by the Democratically-led filibusters of some of Bush's nominees. Even with the presence of a Judiciary Committee majority favorable to the president's nominees, post-committee delay may be increased by a president's hostile relationship to some in the full Senate. Third, obstruction in the confirmation process may be used to "kill" a nominee, but research on the modern judicial confirmation process indicates that Senate obstructionism may be utilized for other purposes as well.

\section{Signaling Theory and Delay in the Confirmation Process}

Confirmation delay may "kill" a nomination by forcing the nominee to withdraw - a tactic that was successful in derailing the confirmation prospects of Boyle, Haynes, and Myers. Delay may as well be used to send a signal to the president concerning his nominee in the hopes of testing the president's determination or extracting concessions regarding subsequent nominees (Bell 2002a; Chase 1972). Senate obstructionism may also be used to signal other actors external to the appointment process. Ferejohn and Shipan (1989) argue that members of Congress sometimes have an incentive to alter their behavior to influence that of administrative agencies. Scherer (2005) brings this aspect of signaling theory into the confirmation process, arguing that obstructionist confirmation tactics are employed to signal to interested groups and partisan elites that their concerns about a particular nominee are being.

Scherer (2005) argues that obstructionist delay is most often employed by the chair of the Judiciary Committee, and that such delay is utilized as a cue to interested activists. However, research on legislative signaling theory focuses on how committees in Congress may provide cues to other members of the legislature. One of the key functions of committees in Congress is to provide expertise (Morrow 1969). Kingdon (1973) argued that uninformed members of Congress look for those with committee expertise to provide substantive cues on policy matters. Krehbiel $(1991,256)$ extended this theory by arguing that committees derive their power in Congress by being 
able to persuade the full chamber "that what the committee wants is in the chamber's best interest." Extended to an analysis of judicial confirmation politics, Senate Judiciary Committee delay may signal opposition to a nominee to other like-minded senators. Of course, the strongest signal is sent when the committee refuses to hold hearings or report a nominee out of committee. However, even for those nominees who succeed in being reported to the floor, the length of time required to reach that stage of the confirmation process may be used as a signal by others in the Senate that at least some members of the Judiciary Committee have strong reservations about the nominee. ${ }^{2}$ Given that all members of the Senate are increasingly interested in using confirmation politics to court favor with interested groups and activists (Bell 2002a; Scherer 2005), senators may be receptive to signals by like-minded obstructionists on the Judiciary Committee. Thus, delay at the committee stage may serve to influence delay at the full Senate stage, even for nominees successfully reported out of committee.

We rely on these previous studies of judicial confirmation politics and legislative signaling theory to analyze the delay experienced by nominees at the committee and full Senate stages of the confirmation process. We are particularly interested in determining what factors influence delay at these distinct phases and whether confirmation obstruction by the Judiciary Committee is used as a cue by those in the full Senate. Given that previous studies have found increased politicization associated with nominations to the circuit courts compared to the district courts (Goldman 2003, Martinek et al. 2002, Stratmann and Garner 2004), we examine district and circuit court confirmation politics separately. We also separate nominees according to whether they were referred during the pre-Bork era of growing political tension in the process, or the post-Bork era where the process became highly politicized and associated with interest group involvement.

\section{Variables and Hypotheses}

Based largely on previous research, we developed a series of hypotheses concerning the use of delay in the confirmation process. These hypotheses consider the influence of nominee characteristics, political factors, the timing of the nomination, and the position being filled. Although previous studies have provided a great deal of information concerning full confirmation delay of nominees, less is known about delay experienced at the Judiciary Committee stage versus the full Senate vote stage. Therefore, except where explicitly noted below, we hypothesize that each variable will have the same influence on both aspects of confirmation delay (Judiciary Committee delay and full Senate vote delay). 


\section{Political Considerations}

All previous studies of confirmation delay incorporated some measure of the president's partisan or ideological relationship to those in the Senate. These studies have included consideration of divided government (Bell 2002b; Binder and Maltzman 2002; Scherer et al. 2008; Sollenberger 2010), the size of the opposing party's delegation in the Senate (Nixon and Goss 2001), the ideological distance between the president and a key member of the Senate (Basinger and Mak 2010; Binder and Maltzman 2002, 2009; Primo et al. 2008; Scherer et al. 2008), and the proportion of opposing-party members on the Judiciary Committee (Martinek et al. 2002). Previous descriptive analyses have found that most of the delay seen in the modern confirmation process occurs at the committee stage (Goldman 2003; Goldman et al. 2011; Slotnick and Goldman 1998), and that the Judiciary Committee chair is particularly important in determining the extent of delay imposed by the committee (Scherer 2005). Thus, we hypothesize that the committee chair's relationship to the president will have an influence on the extent of delay imposed on nominees by the Senate Judiciary Committee.

$\mathrm{H}_{1}$ : When the ideological distance between the president and the Senate Judiciary Committee chair is greater, nominees will experience more delay at the committee stage than when the ideological distance is smaller.

In addition, previous research on confirmation politics has focused on the important role played by the filibuster pivot in the Senate (Holmes 2007; Johnson and Roberts 2004, 2005; Moraski and Shipan 1999; Nixon and Goss 2001; Primo et al. 2008). Acknowledging Krehbiel's (1998) pivotal politics theory, Johnson and Roberts explain that the theory "holds that supermajoritan institutions - such as the Senate filibuster and the presidential veto-have an important influence on the legislative process because policy makers often must obtain large supermajority coalitions to secure passage of legislation” (2005, 33). Similar to Johnson and Roberts (2005), we recognize that although Krehbiel does not explicitly reference the judicial nomination process, his theory indicates that a president must consider more than a simple majority needed for judicial nominees, especially those for the circuit courts. As other scholars (e.g., Holmes 2007; Nixon and Goss 2001; Primo et al. 2008) have done, we employ the filibuster pivot to measure the need for a president to account for nominees' potential filibusters. We hypothesize that the president's ideological relationship to the filibuster pivot in the Senate will have an influence on delay experienced at the hands of the full Senate. Although many recent studies of confirmation delay have incorporated ideological variables rather than measures of partisan control, 
we ran each model incorporating a simple dummy variable measuring whether or not the nominee was referred during a period of unified or divided government, with similar results to the models incorporating the ideological distance variables. ${ }^{3}$

$\mathbf{H}_{2}$ : When the ideological distance between the president and the Senate filibuster pivot is greater, nominees will experience more delay at the Senate vote stage than when the ideological distance is smaller.

The presence or absence of home-state senators of the president's party have been shown to influence the confirmation process (Bell 2002b; Solowiej et al. 2005; Stratmann and Garner 2004). When a president is better able to work in conjunction with, rather than opposition to, the homestate Senate delegation, our expectation is that the president's nominees will be treated better by those in the Senate. We expect that this relationship will hold across both phases of the confirmation process.

$\mathbf{H}_{3}$ : A nominee with more home-state senators of the president's party will experience less delay than a nominee with fewer homestate senators of the president's party.

A nominee may also benefit by having a home-state ally in a position of importance in the confirmation process. Although we would expect this variable to be most influential with respect to how much delay occurs at the hands of the Senate Judiciary Committee, previous scholarship has found a home-state insider to be beneficial to delay experienced throughout the confirmation process. Stratmann and Garner (2004) found that nominees faced less delay when a home-state ally was the chair or ranking member of the Senate Judiciary Committee. Bell (2002b) found that a home-state ally on the Judiciary Committee sped up the process, regardless of party affiliation or the presence of divided government.

$\boldsymbol{H}_{4}$ : A nominee with a home-state insider on the Senate Judiciary Committee will experience less delay than a nominee without a committee insider.

Among the various political factors to consider, Bell (2002b) found that nominees experience more delay when interest groups were involved in the confirmation process. In addition, Scherer et al. $(2008,1038)$ argued that interest group opposition is "the key to understanding lower court confirmation politics," at least since the mid-1980s. The modern judicial confirmation process now encourages all actors in the Senate (not just those on the 
Judiciary Committee) to use confirmation politics to appeal to their interested observers (Bell 2002a). Thus, we expect that interest group opposition will have the following influence on both phases of the confirmation process:

$\boldsymbol{H}_{5}$ : Nominees subject to opposition by interest groups will face more delay than will nominees without interest group opposition.

\section{The Timing of the Nomination}

In addition to the political context surrounding the confirmation process, previous studies have found a relationship between confirmation delay and the presidential election cycle, with nominations made later in a presidential term experiencing more delay than those referred earlier (Martinek et al. 2002; Nixon and Goss 2001; Solowiej et al. 2005). Furthermore, Martinek et al. (2002) found that judicial nominees were treated less favorably when referred in a president's second term.

$\boldsymbol{H}_{6}:$ A nominee referred later in a presidential term will experience more delay in the confirmation process than will nominees referred earlier in the president's term.

$\boldsymbol{H}_{7}$ : A nominee referred in a president's second term will experience more delay in the confirmation process than will first term nominees.

\section{Characteristics of the Seat Being Filled}

Previous research indicates that certain appointments to the U.S. Supreme Court and the courts of appeals are considered to be more "critical" than others. Ruckman (1993) distinguished "critical nominations" as those replacing a judge of the opposite party, particularly when such a replacement would have a greater impact on the overall ideological composition of the Supreme Court. Shipan and Shannon (2003) similarly defined "critical nominations" as those that would have a substantial influence on the partisan balance of the Supreme Court, finding that such nominations experienced increased delay in the confirmation process. Binder and Maltzman (2002) found that confirmation delay was greater for circuit court nominees who would shift the partisan balance of an evenly divided circuit, at least during periods of divided government. Given that studies incorporating district court confirmation politics did not include such consideration (see Martinek et al. 2002; Solowiej et al. 2005), we only hypothesize a relationship between nominations that shift the partisan balance of the bench and confirmation delay for nominees to the courts of appeals. 
$\boldsymbol{H}_{8}$ : For nominees to the U.S. Courts of Appeals, confirmation delay will be greater for nominees representing a greater partisan change on the circuit than for other nominees.

In addition to greater conflict surrounding nominations that would have a more substantial impact on the partisan distribution of a particular court, recent scholarship has highlighted the contention that may follow a vacancy from one president to the next (Goldman et al. 2005). In particular, some seats (such as those on the Sixth Circuit Court of Appeals in recent years) have become controversial because confirmation gridlock of one president's nominees has been viewed as unfairly benefiting that president's oppositeparty successor (Goldman et al. 2005). As such, we hypothesize that:

$\boldsymbol{H}_{9}$ : Nominees referred to vacancies inherited by opposite-party presidents will experience lengthier confirmation delay than will nominees referred to other vacancies.

\section{Nominee Characteristics}

Many previous studies have found higher American Bar Association ratings of a nominee to have a beneficial influence on the length of time spent in the confirmation process (Allison 1996; Hartley 2001; Martinek et al. 2002; Solowiej et al. 2005; Stratmann and Garner 2004). In 1997, Senate Judiciary Committee Chair Orrin Hatch (R-UT) announced that ABA ratings would no longer play an official role in the confirmation process (Goldman and Slotnick 1999). Later, President George W. Bush eliminated ABA ratings from the formal nominee selection process (Goldman et al. 2005; Holmes and Savchak 2003). However, the ABA continued to vet nominees (Holmes 2007; Soloweij et al. 2005), and individual senators were free to consider nominee ratings in the confirmation process. Also, President Bush himself proved willing to highlight the quality of his nominees by touting their ABA ratings, and the ABA place in the nominee selection process would be reinstated by President Obama (Goldman et al. 2011). ${ }^{4}$ Therefore, although the ABA's formal role in the appointment process has not been consistent over time, we expect ABA ratings as a proxy for nominee quality to influence committee and full Senate delay throughout the time period of our analysis:

$\boldsymbol{H}_{10}$ : Nominees with higher $A B A$ ratings will experience less delay in the confirmation process than will nominees with lower $A B A$ ratings. 
Past studies have found mixed results as to whether minority or female nominees have been delayed longer in the process of confirmation than have white, male nominees. Some studies (such as Hartley 2001) suggested that when we look at different presidencies, being a minority may not matter, while gender may be of slightly more importance. Some multivariate studies found nominee ethnicity and gender to be significant and in the predicted direction (Bell 2002b; Nixon and Goss 2001) while others found less clear influence of these factors (Martinek et al. 2002). Solowiej et al. (2005) found evidence that being a minority or female may be more or less important depending upon the party of the appointing president. Although previous findings on nominee ethnicity and gender and confirmation delay are inconclusive, we hypothesize that both nominee minority status and gender will have an influence on delay in the confirmation process.

$\boldsymbol{H}_{11}$ : Minority nominees will experience longer delays in the confirmation process than will be experienced by non-minority nominees.

$\boldsymbol{H}_{12}$ : Female nominees will experience more delay than will male nominees.

\section{Committee Influence on the Full Senate}

Based on previous research on the role of committees in the legislature, we were interested in determining whether the committee's treatment of a nominee influenced delay at the hands of the full Senate. The power of committees in Congress is derived from their expertise and ability to transfer their preferences to others in the legislature (Kingdon 1973; Krehbiel 1991). Thus, we expect delay at the committee stage to influence delay at the full Senate stage as non-committee members pick up on the obstructionist cue provided by those on the Judiciary Committee. Our final hypothesis in this analysis is therefore related only to delay exhibited at the Senate vote stage. We expect this signaling influence to be particularly apparent in the district court confirmation process, given the decreased saliency and increased regularity of these nominations. Thus, delay cues given by the Senate Judiciary Committee are expected to influence full Senate delay for less high-profile nomination to the district courts in particular.

$\boldsymbol{H}_{13}$ : Nominees who experience greater delay prior to being reported out of committee will experience more delay before final Senate action is taken than will nominees experiencing less delay at the hands of the Judiciary Committee. 


\section{Data, Variables, and Methods}

In order to examine the politics of delay in the confirmation process, we collected information on all 1805 district and circuit court nominees referred to the Senate between 1977 and $2010 .^{5}$ We collected information on the political climate at the time of nominee referral, the timing of the referral relative to the point in the president's term, characteristics of the position being filled, and characteristics of the individual nominated. Due to missing data for some variables, we had full data for 1800 nominees. Given that we were interested in the length of delay experienced by individuals throughout the confirmation process, we did not classify distinct nominations of a single individual by one president as distinct cases. Rather, we tracked individual nominees throughout the confirmation process, continuing across Senate recesses and repeated re-nominations of the same individual by a president. ${ }^{6}$

\section{Dependent Variables}

Our interest in examining delay at distinct phases of the confirmation process required developing multiple dependent variables designed to measure delay associated with treatment by the Senate Judiciary Committee as well as that experienced at the hands of the full Senate in voting to confirm nominees. The first dependent variable in our analysis measured the length of time a nominee was considered by the Senate Judiciary Committee. This variable (committee delay) was measured as the number of days between the nominee's original referral date to the date the nominee was reported out of committee. For nominees who were never reported out of committee, the committee delay variable was coded as the number of days between the original referral date and the date the nomination ended in withdrawal or return to the president. Due to the statistical approach utilized for our analysis, a related variable (report success) was developed denoting whether or not the nominee was reported out of committee.

Our second dependent variable was designed to measure the delay imposed on nominees after the nomination was reported out of committee. This variable (Senate vote delay) was measured as the number of days between the nominee's report out of committee and that nominee's final resolution at the hands of the Senate. ${ }^{7}$ Individuals never reported out of committee were excluded from this part of our analysis, resulting in 1589 total cases included in the Senate vote delay models. Similarly as above, our statistical approach required the inclusion of a related variable (confirmation success) denoting whether or not the nominee was successfully confirmed by the full Senate. 


\section{Independent Variables}

We developed a series of independent variables based on our theoretical hypotheses. The president's ideological relationship to those in the Senate was measured using 1st dimension DW-NOMINATE scores (Poole and Rosenthal 1997) to calculate the absolute distance in the ideological scores for the president and the furthest filibuster pivot (located at the 40th and 60th percentiles, see Binder 1999) in the Senate (president-filibuster pivot distance). ${ }^{8}$ We also used the DW-NOMINATE scores to determine the absolute ideological distance between the president and the chair of the Judiciary Committee (president-Senate Judiciary Committee Chair distance). ${ }^{9}$ The variable included to determine the influence of senatorial courtesy on confirmation delay (home-state senators) measured the number of homestate senators of the same party as the president at the time the nominee was originally referred. We also included a dichotomous variable measuring whether or not the nominee had a home-state ally (of either party) seated on the Judiciary Committee at the time of original referral (committee insider). To determine the influence of interest group opposition on confirmation delay, we included a dichotomous variable that identified nominees who were the subject of interest group opposition. ${ }^{10}$ Some of the data for this variable (interest group opposition) were collected from Scherer's (2005, see Table 5-1) analysis of interest group involvement in the lower court appointment process. We gathered the data for the nominees during the remaining years of the $\mathrm{W}$. Bush administration and for the Obama administration's nominees following the method described in Scherer et al. (2008), which measures interest group opposition based on the presence or absence of at least two national interest groups (or an umbrella national interest group) who opposed the nominee.

Two variables were incorporated to measure the timing of the nomination vis-à-vis the president's term of office. Following Martinek et al. (2002), the first variable (year in presidential term) was coded as the year (one through four) of the president's term in which the nominee was referred. The second variable (second term nominee) was a dichotomous variable coded as " 1 " if the nominee was referred in the second term of a president's administration, and " 0 " otherwise.

Two variables were developed concerning the characteristics of the seat being filled. For seats on the circuit courts only, we developed a variable measuring whether or not a nominee would alter the partisan balance of a circuit (partisan change on circuit). Given that circuits differ in size, we measured the proportional increase in the partisan composition of the circuit represented by the addition of the nominee. For circuit and district court 
positions, we developed a dichotomous variable (inherited seat) measuring whether or not the seat was inherited by an opposite-party president.

Three nominee-specific variables were developed. We coded the $A B A$ rating variable on a six point scale (see Martinek et al. 2002), with a " 6 " indicating nominees with the highest ratings, and a " 1 " indicating nominees with the lowest ratings. We included a dichotomous variable (minority) coded as " 1 " for any nominee classified as a racial or ethnic minority, ${ }^{11}$ and " 0 " otherwise. Our last nominee-specific variable (gender) was coded as " 1 " for female nominees and " 0 " for male nominees.

In the full Senate vote models, we included a variable measuring delay at the committee stage of the process. We therefore used the committee delay dependent variable discussed previously as an independent variable in the Senate vote delay model. This variable measured the time in days between a nominee's original referral date and the date the nominee was reported out of committee.

Descriptive data on confirmation delay for nominees separated by court level and timing of the nomination are provided in Table 1 . These descriptive data indicate that confirmation delay during both distinct phases of the confirmation process was greater after the Bork nomination than it was prior to 1987. After the Bork nomination, furthermore, confirmation delay was much greater for circuit court nominees than for district court nominees. Our descriptive findings support the decision by previous researchers to conduct separate analyses for each court level, as well as the decision to consider the timing of a nomination relative to the Bork hearing (Martinek et al. 2002).

\section{Table 1. Confirmation Delay by Court Level and Timing of Nomination (In days, standard deviations in parentheses)}

\begin{tabular}{lcccc}
\hline Variable & $\begin{array}{c}\text { Pre-Bork } \\
\text { Circuit } \\
\text { Nominees }\end{array}$ & $\begin{array}{c}\text { Post-Bork } \\
\text { Circuit } \\
\text { Nominees }\end{array}$ & $\begin{array}{c}\text { Pre-Bork } \\
\text { District } \\
\text { Nominees }\end{array}$ & $\begin{array}{c}\text { Post-Bork } \\
\text { District } \\
\text { Nominees }\end{array}$ \\
\hline Committee report time & $\begin{array}{c}67.37 \\
(76.19)\end{array}$ & $\begin{array}{c}248.24 \\
(265.59)\end{array}$ & $\begin{array}{c}66.50 \\
(74.17)\end{array}$ & $\begin{array}{c}137.68 \\
(145.61)\end{array}$ \\
& $\mathrm{N}=139$ & $\mathrm{~N}=245$ & $\mathrm{~N}=482$ & $\mathrm{~N}=934$ \\
Time from report & 11.38 & 76.12 & 7.75 & 30.74 \\
to confirmation* & $(26.62)$ & $(149.91)$ & $(26.39)$ & $(52.27)$ \\
& $\mathrm{N}=131$ & $\mathrm{~N}=189$ & $\mathrm{~N}=467$ & $\mathrm{~N}=802$ \\
*For the Senate vote delay variable, all cases where the nominee was not reported out of committee \\
were dropped. Therefore, the N's for this variable are different than for the committee delay vari- \\
able.
\end{tabular}


These findings follow previous descriptive analyses in pointing to the importance of the Bork nomination and the 100th Congress as a turning point for contention within the modern confirmation process (Bell 2002a; Epstein et al. 2006; Scherer 2005; Slotnick and Goldman 1998). These descriptive findings therefore substantiate our decision to conduct separate analyses for nominees based on court level and timing relative to the Bork nomination.

\section{Methods}

For each of the dependent variables in our analysis (committee delay and Senate vote delay) we ran four different Cox Proportional Hazards models in order to conduct separate analyses for circuit and district court nominees, as well as for those nominated before and after the failed nomination of Robert Bork. We used Cox Proportional Hazards models rather than a fully parametric method because we have no theoretical expectation concerning the distribution for the time until confirmation (see Binder and Maltzman 2004, 12). A Cox model is also less restrictive than a Weibull model in terms of the assumptions imposed (see Box-Steffensmeier and Jones 2004, 62). For each of the Cox models, the coefficients show whether a variable increases or decreases the hazard rate. An increase in the hazard rate (a positive coefficient) means that the variable has the effect of shortening the confirmation process while a decrease in the hazard rate (negative coefficient) has the opposite effect of lengthening the confirmation process.

We assessed the adequacy of each model using Cox-Snell Residuals (Binder and Maltzman 2004; Box-Steffensmeier and Jones 2004), finding that each model was adequately specified. We also tested the proportional hazards assumption implicit in a Cox model (Box-Steffensmeier and Jones 2004, Binder and Maltzman 2004). The "term 'proportional hazard' refers to the effect of any covariate having a proportional and constant effect that is invariant to when in the process the value of the covariate changes" (BoxSteffensmeier and Jones 2004, 132). In essence, "each observation's hazard function follows exactly the same pattern over time" (Box-Steffensmeier and Jones 2004, 132). For variables that violated the proportional hazards assumption, we included an interactive effect between the problematic variable and the natural logarithm of time (see Binder and Maltzman 2004; BoxSteffensmeier and Jones 2004).

\section{Results}

\section{Circuit Court Nominees}

Results for the various Cox models measuring delay in the circuit court confirmation process are provided in Tables 2 (committee delay) and 3 
(Senate vote delay). At each distinct phase, important information emerges before and after the failed Bork nomination. Prior to the Bork nomination, when confirmation politics were less contentious, committee delay was not affected by many of our political variables (see Table 2). The president's relationship to the Judiciary Committee chair and the home state Senate contingent had no statistically significant influence on delay at the committee stages. However, even though interest groups were not fully organized and

\section{Table 2. Cox Regression of Time from Referral to Committee Report, Circuit Court Nominees (1977-2010)}

\begin{tabular}{|c|c|c|}
\hline Variables & $\begin{array}{c}\text { Pre-Bork Nominees } \\
\text { Coefficient } \\
\text { (Robust s.e.) }\end{array}$ & $\begin{array}{l}\text { Post-Bork Nominees } \\
\text { Coefficient } \\
\text { (Robust s.e.) }\end{array}$ \\
\hline Pres-SJC chair distance & $\begin{array}{l}-0.554 \\
(0.408)\end{array}$ & $\begin{array}{l}-1.026^{* * *} \\
(0.210)\end{array}$ \\
\hline Home-state senators & $\begin{array}{l}-0.063 \\
(0.111)\end{array}$ & $\begin{array}{c}0.090 \\
(0.083)\end{array}$ \\
\hline Committee insider & $\begin{array}{c}0.184 \\
(0.272)\end{array}$ & $\begin{array}{c}0.182 \\
(0.148)\end{array}$ \\
\hline Interest group opposition & $\begin{array}{l}-1.009 * * \\
(0.299)\end{array}$ & $\begin{array}{l}-0.987 * * * \\
(0.180)\end{array}$ \\
\hline Year in presidential term & $\begin{array}{l}-0.635 * * * \\
(0.122)\end{array}$ & $\begin{array}{l}-0.190 * * \\
(0.073)\end{array}$ \\
\hline Second term nominee & $\begin{array}{l}-0.181 \\
(0.297)\end{array}$ & $\begin{array}{l}-0.786^{* * *} \\
(0.199)\end{array}$ \\
\hline Partisan change on circuit & $\begin{array}{c}1.017 \\
(2.631)\end{array}$ & $\begin{array}{c}1.692 \\
(1.734)\end{array}$ \\
\hline Inherited seat & $\begin{array}{l}-0.386 \\
(0.537)\end{array}$ & $\begin{array}{l}-0.491^{* *} \\
(0.180)\end{array}$ \\
\hline ABA rating & $\begin{array}{c}0.075 \\
(0.069)\end{array}$ & $\begin{array}{l}0.168^{* *} \\
(0.054)\end{array}$ \\
\hline Race & $\begin{array}{l}-0.199 \\
(0.357)\end{array}$ & $\begin{array}{c}0.185 \\
(0.165)\end{array}$ \\
\hline \multirow[t]{2}{*}{ Gender } & $\begin{array}{l}-0.131 \\
(0.273)\end{array}$ & $\begin{array}{l}-0.051 \\
(0.176)\end{array}$ \\
\hline & $\begin{array}{l}\mathrm{N}=139 \\
\text { Log likelihood }=-500.72 \\
\text { Chi-square }=57.02^{* * *}\end{array}$ & $\begin{array}{l}\mathrm{N}=245 \\
\text { Log likelihood }=-837.39 \\
\text { Chi-square }=103.03^{* * *}\end{array}$ \\
\hline Two-tailed tests: $\# \mathrm{p}<.10 ;{ }^{*} \mathrm{p}<$. & ${ }^{*} \mathrm{p}<.01 ; * * * \mathrm{p}<.001$ & \\
\hline
\end{tabular}


involved in the confirmation process prior to the mid-1980s (Scherer 2005), we find that pre-Bork nominees subjected to interest group opposition faced more delay at the committee stage than did other nominees. Nominees referred later in a president's term as well experienced more delay than did those referred in earlier years. None of the nominee-specific variables had a statistically significant impact on committee delay.

Subsequent to the Bork nomination, political considerations did influence committee delay of circuit court nominees. Nominees were delayed when the president was ideologically distant from the Judiciary Committee Chair, as well as when the nominee was targeted by interest group opposition. Electoral considerations affected the committee process in the postBork era, with nominees forwarded later in the president's term and in the second term experiencing greater delay. In addition, a vacancy inherited from an opposite-party president resulted in greater committee delay. Lastly, nominees with higher ABA ratings were handled more quickly than those with lower ratings. Our results indicate that many of the factors that we associate with confirmation delay (electoral politics and the president's ideological relationship to those in the Senate, for example) had a greater influence on Senate Judiciary Committee behavior in the years subsequent to the crucial Bork nomination to the Supreme Court than they did in earlier years.

Our results for delay of circuit court nominees at the hands of the full Senate are provided in Table 3. The model of pre-Bork full Senate delay of circuit court nominees displayed evidence that the proportional hazards assumption was violated by one or more variables in the model. ${ }^{12}$ Some of our results in this model differed depending on whether we corrected for all variables that showed evidence of violating the assumption or only the variable (interest group opposition) that proved the most significant violator of the assumption. Given this relative instability of this model compared to the others in this analysis, we have somewhat less confidence in the results of the model measuring full Senate delay of circuit court nominations in the pre-Bork era.

Prior to the Bork nomination, full Senate delay of circuit court nominees appears to be influenced by the president's ideological relationship to the key senator representing the filibuster pivot. However, the direction of this influence was in the opposite direction than predicted, with nominees being handled more quickly when the president's relationship with the filibuster pivot was ideologically distant. Possibly, this demonstrates that in the earlier years of the contemporary appointment process, the threat of a filibuster over nominees who made it through the committee stage was not particularly severe. Thus, in the pre-Bork years, when the president's relationship to the Senate was less friendly, the committee was considered the most significant gatekeeper, and nominees who made it out of committee 


\section{Table 3. Cox Regression of Time from Committee Report to Senate Vote, Circuit Court Nominees (1977-2010)}

\begin{tabular}{|c|c|c|}
\hline Variables & $\begin{array}{l}\text { Pre-Bork Nominees } \\
\text { Coefficient } \\
\text { (Robust s.e.) }\end{array}$ & $\begin{array}{l}\text { Post-Bork Nominees } \\
\text { Coefficient } \\
\text { (Robust s.e.) }\end{array}$ \\
\hline Committee report time & $\begin{array}{c}0.001 \\
(0.002)\end{array}$ & $\begin{array}{l}-0.001 * * \\
(0.000)\end{array}$ \\
\hline Pres-filibuster distance & $\begin{array}{l}2.379 * * \\
(0.707)\end{array}$ & $\begin{array}{c}0.782 \\
(0.680)\end{array}$ \\
\hline Home-state senators & $\begin{array}{l}0.399 * \\
(0.169)\end{array}$ & $\begin{array}{l}-0.079 \\
(0.091)\end{array}$ \\
\hline $\begin{array}{l}\text { Home-state senators } \\
\mathrm{x} \log (\text { time })\end{array}$ & $\begin{array}{l}-0.159 \\
(0.123)\end{array}$ & - \\
\hline Committee insider & $\begin{array}{c}0.156 \\
(0.145)\end{array}$ & $\begin{array}{l}-0.208 \\
(0.152)\end{array}$ \\
\hline Interest group opposition & $\begin{array}{c}1.428 \\
(1.867)\end{array}$ & $\begin{array}{l}-1.039 * * * \\
(0.205)\end{array}$ \\
\hline $\begin{array}{l}\text { Interest group opposition } \\
\mathrm{x} \log (\text { time })\end{array}$ & $\begin{array}{l}-0.756 \\
(0.637)\end{array}$ & - \\
\hline Year in presidential term & $\begin{array}{l}0.536^{* * *} \\
(0.102)\end{array}$ & $\begin{array}{c}0.164^{\#} \\
(0.095)\end{array}$ \\
\hline $\begin{array}{l}\text { Year in presidential term } \\
\mathrm{x} \text { log(time) }\end{array}$ & $\begin{array}{l}-0.495 * * * \\
(0.062)\end{array}$ & - \\
\hline Second term nominee & $\begin{array}{l}-0.647 * \\
(0.299)\end{array}$ & $\begin{array}{l}-0.034 \\
(0.176)\end{array}$ \\
\hline Partisan change on circuit & $\begin{array}{l}-0.367 \\
(1.591)\end{array}$ & $\begin{array}{c}2.902 \\
(1.813)\end{array}$ \\
\hline Inherited seat & $\begin{array}{c}0.227 \\
(0.396)\end{array}$ & $\begin{array}{l}-0.130 \\
(0.221)\end{array}$ \\
\hline ABA rating & $\begin{array}{l}0.529 * * * \\
(0.110)\end{array}$ & $\begin{array}{c}0.058 \\
(0.055)\end{array}$ \\
\hline $\begin{array}{l}\text { ABA rating } \\
\mathrm{x} \log (\text { time })\end{array}$ & $\begin{array}{l}-0.293 * * * \\
(0.051)\end{array}$ & - \\
\hline Race & $\begin{array}{l}0.544^{* *} \\
(0.192)\end{array}$ & $\begin{array}{l}-0.300 \\
(0.203)\end{array}$ \\
\hline \multirow[t]{2}{*}{ Gender } & $\begin{array}{c}0.450 \\
(0.278)\end{array}$ & $\begin{array}{l}-0.008 \\
(0.166)\end{array}$ \\
\hline & $\begin{array}{l}\mathrm{N}=131 \\
\text { Log likelihood }=-366.40 \\
\text { Chi-square }=244.04^{* * *}\end{array}$ & $\begin{array}{l}\mathrm{N}=189 \\
\text { Log likelihood }=-738.40 \\
\text { Chi-square }=64.59^{* * *}\end{array}$ \\
\hline
\end{tabular}


were expedited to confirmation. We do find some evidence in the pre-Bork years that full Senate delay of circuit court nominees was affected in the expected ways by electoral politics, nominee characteristics, and the president's relationship with the home-state contingent, however.

The delay experienced at the hands of the Senate Judiciary Committee did not have an affect on the full Senate delay in the pre-Bork era. Subsequent to the Bork nomination, however, nominees who experienced greater delay at the committee stage were likely to experience greater delay at the full Senate stage as well, even when controlling for other potential delayinducing factors, such as interest group involvement or ideology of the president relative to the filibuster pivot. This is an important finding that indicates that at least in the post-Bork years, those in the full Senate pick up on committee delay as an independent cue that a nominee is to be subjected to heightened scrutiny by the full Senate as well. Nominees subjected to interest group opposition were further delayed, although those nominated later in the president's term were subjected to less delay by the full Senate (although only at the $\mathrm{p}<.10$ level). Our results indicate that full Senate delay of circuit court nominations since 1987 are largely driven by two factors: the presence of interest group opposition and committee delay. Other political, ideological, seat-specific, or nominee-specific factors do not have a significant influence on full Senate delay of these nominees.

\section{District Court Nominees}

The results of the Cox models measuring delay in the confirmation process for district court nominees are provided in Tables 4 (committee delay) and 5 (Senate vote delay). The results in Table 4 indicate that committee delay of district court nominees was driven by a variety of political, electoral, and nominee-specific factors in the pre-Bork years. The president's weakened ideological relationship to the Senate Judiciary Committee Chair, the timing of the nomination relative to presidential electoral politics, and the presence of interest group opposition each influenced committee delay in the expected direction. In the early era of our analysis, furthermore, nonwhite nominees were delayed more extensively then were white nominees, whereas nominees rated more highly by the ABA were treated more expeditiously than were nominees rated less favorably. Having a home-state insider on the Senate Judiciary Committee had the expected affect of speeding up the confirmation process, although the relationship was only significant at the $\mathrm{p}<.10$ level.

Subsequent to the Bork hearing, Judiciary Committee treatment of district court nominees were affected by an array of political and electoral considerations, similar to the pre-Bork years. The Senate Judiciary Committee 
Table 4. Cox Regression of Time from Referral to Committee Report, District Court Nominees (1977-2010)

\begin{tabular}{|c|c|c|}
\hline Variables & $\begin{array}{l}\text { Pre-Bork Nominees } \\
\text { Coefficient } \\
\text { (Robust s.e.) }\end{array}$ & $\begin{array}{l}\text { Post-Bork Nominees } \\
\text { Coefficient } \\
\text { (Robust s.e.) }\end{array}$ \\
\hline Pres-SJC chair distance & $\begin{array}{l}-0.476^{*} \\
(0.199)\end{array}$ & $\begin{array}{l}-0.372 * * * \\
(0.106)\end{array}$ \\
\hline Home-state senators & $\begin{array}{c}0.081 \\
(0.065)\end{array}$ & $\begin{array}{l}0.148^{* *} \\
(0.044)\end{array}$ \\
\hline Committee insider & $\begin{array}{c}0.209^{\#} \\
(0.107)\end{array}$ & $\begin{array}{l}-0.027 \\
(0.072)\end{array}$ \\
\hline Interest group opposition & $\begin{array}{l}-1.696^{* * *} \\
(0.318)\end{array}$ & $\begin{array}{l}-0.924^{* *} \\
(0.275)\end{array}$ \\
\hline Year in presidential term & $\begin{array}{l}-0.457 * * * \\
(0.055)\end{array}$ & $\begin{array}{l}-0.222 * * * \\
(0.040)\end{array}$ \\
\hline Second term nominee & $\begin{array}{l}-0.281^{*} \\
(0.142)\end{array}$ & $\begin{array}{l}-0.349 * * * \\
(0.084)\end{array}$ \\
\hline Inherited seat & $\begin{array}{c}0.037 \\
(0.274)\end{array}$ & $\begin{array}{l}-0.116 \\
(0.116)\end{array}$ \\
\hline ABA rating & $\begin{array}{c}0.068 * \\
(0.033)\end{array}$ & $\begin{array}{l}0.105^{* * * *} \\
(0.025)\end{array}$ \\
\hline Race & $\begin{array}{l}-0.363^{*} \\
(0.149)\end{array}$ & $\begin{array}{c}0.022 \\
(0.086)\end{array}$ \\
\hline \multirow[t]{2}{*}{ Gender } & $\begin{array}{c}0.096 \\
(0.140)\end{array}$ & $\begin{array}{c}0.088 \\
(0.081)\end{array}$ \\
\hline & $\begin{array}{l}\mathrm{N}=482 \\
\text { Log likelihood }=-2393.97 \\
\text { Chi-square }=138.85^{* * *}\end{array}$ & $\begin{array}{l}\mathrm{N}=934 \\
\text { Log likelihood }=-4743.98 \\
\text { Chi-square }=116.32 * * *\end{array}$ \\
\hline Two-tailed tests: $\# \mathrm{p}<.10 ;{ }^{*} \mathrm{p}$ & $\mathrm{p}<.01 ; * * * \mathrm{p}<.001$ & \\
\hline
\end{tabular}

engaged in greater delay of nominees forwarded later in the president's term, in the president's second term, when the president's relationship to the committee chair was less favorable, and when interest groups opposed the nominee. Nominees were treated more favorably, however, then the home-state Senate contingent was more aligned with the president's partisan identification, and when the nominee was rated more highly by the ABA. When it comes to the Judiciary Committee's treatment of district court nominees, then, there is more similarity than difference between the pre-Bork and postBork years. 
The results for full Senate treatment of district court nominees are provided in Table 5. In the earlier, less contentious era of our analysis, full Senate delay of district court nominees was increased in response to electoral politics and interest group opposition. There was no influence of either the president's ideological relationship to the senator representing the filbuster pivot or the Judiciary Committee's treatment of the nominee.

Table 5. Cox Regression of Time from Committee Report to Senate Vote, District Court Nominees (1977-2010)

\begin{tabular}{|c|c|c|}
\hline Variables & $\begin{array}{l}\text { Pre-Bork Nominees } \\
\text { Coefficient } \\
\text { (Robust s.e.) }\end{array}$ & $\begin{array}{l}\text { Post-Bork Nominees } \\
\text { Coefficient } \\
\text { (Robust s.e.) }\end{array}$ \\
\hline Committee report time & $\begin{array}{l}-0.001 \\
(0.001)\end{array}$ & $\begin{array}{l}-0.001^{* *} \\
(0.000)\end{array}$ \\
\hline Pres-filibuster distance & $\begin{array}{c}0.353 \\
(0.484)\end{array}$ & $\begin{array}{c}0.030 \\
(0.285)\end{array}$ \\
\hline Home-state senators & $\begin{array}{l}-0.106 \\
(0.076)\end{array}$ & $\begin{array}{l}-0.026 \\
(0.045)\end{array}$ \\
\hline Committee insider & $\begin{array}{c}0.227^{*} \\
(0.113)\end{array}$ & $\begin{array}{l}-0.261^{* * *} \\
(0.074)\end{array}$ \\
\hline Interest group opposition & $\begin{array}{l}-1.577^{\#} \\
(0.943)\end{array}$ & $\begin{array}{l}-1.714^{* * *} \\
(0.420)\end{array}$ \\
\hline Year in presidential term & $\begin{array}{l}-0.155^{*} \\
(0.061)\end{array}$ & $\begin{array}{c}0.077 * \\
(0.038)\end{array}$ \\
\hline Second term nominee & $\begin{array}{l}-0.768 * * * \\
(0.179)\end{array}$ & $\begin{array}{l}-0.258 * * \\
(0.075)\end{array}$ \\
\hline Inherited seat & $\begin{array}{r}0.445^{\#} \\
(0.227)\end{array}$ & $\begin{array}{c}0.124 \\
(0.164)\end{array}$ \\
\hline ABA rating & $\begin{array}{c}0.057^{\#} \\
(0.033)\end{array}$ & $\begin{array}{l}-0.038 \\
(0.026)\end{array}$ \\
\hline Race & $\begin{array}{c}0.302 * \\
(0.134)\end{array}$ & $\begin{array}{l}-0.212 * \\
(0.096)\end{array}$ \\
\hline \multirow[t]{2}{*}{ Gender } & $\begin{array}{c}0.085 \\
(0.170)\end{array}$ & $\begin{array}{l}-0.298 * * \\
(0.087)\end{array}$ \\
\hline & $\begin{array}{l}\mathrm{N}=467 \\
\text { Log likelihood }=-2376.10 \\
\text { Chi-square }=71.39 * * *\end{array}$ & $\begin{array}{l}\mathrm{N}=802 \\
\text { Log likelihood }=-4424.96 \\
\text { Chi-square }=73.51^{* * *}\end{array}$ \\
\hline
\end{tabular}

Two-tailed tests: $\# \mathrm{p}<.10 ;{ }^{*} \mathrm{p}<.05 ;{ }^{* *} \mathrm{p}<.01 ;{ }^{* * *} \mathrm{p}<.001$ 
Nominees were benefitted, however, by experiencing lesser delay when there was a home-state insider on the Judiciary Committee. Nominees in the earlier era were also benefitted by the nominee-specific factors associated with $\mathrm{ABA}$ rating and race.

In the pre-Bork era, we found that nominees were handled more quickly by the full Senate when the nominating president had inherited the vacancy from a previous president, although only at the $\mathrm{p}<.10$ level. This finding is contrary to our initial expectations, however it makes some sense that filling an inherited seat on the district court in the pre-Bork years would not be particularly problematic. During those years, district court vacancies that arose late in a president's term were often inherited by the succeeding president due to simple timing considerations rather than concerted efforts to obstruct the outgoing president's opportunity to fill the vacancy. As such, somewhat expeditious confirmation to these hold-over vacancies is understandable.

As with the model of the full Senate's treatment of circuit court nominees in the pre-Bork years, there is some evidence of instability related to the proportional hazards assumption in the model of full Senate treatment of post-Bork district court nominees. This instability is most specifically associated with the variable measuring the president's ideological relationship to the filibuster pivot in the Senate. There is weak evidence that this variable violates the proportional hazards assumption, but applying the relevant fix to this variable causes the model to become unstable. As such, we provide results in Table 5 without the interactive variable that would correct for the assumption violation with this variable.

In this model, nominees associated with interest group opposition, those nominated in the president's second term, and those subjected to increased delay at the committee stage were all delayed further by the full Senate. As with post-Bork circuit court nominations, those district court nominees forwarded later in the president's term were handled more quickly by the full Senate. Female and non-white nominees were delayed more by the full Senate than were their male and white counterparts. Lastly, those with an insider on the Senate Judiciary Committee were treated less favorably by the full Senate. We cannot account fully for this result. Perhaps those in the full Senate give somewhat greater scrutiny to these nominees due to a perception that those with an insider on the committee were not vetted as fully by the committee.

\section{Discussion and Conclusions}

Our findings support an approach that examines the distinct phases of the confirmation process. In doing so, we have been able to demonstrate that 
certain factors have a similar impact on delay at each distinct stage. Opposition to the nominee by interested groups, for example, was found to influence delay at both stages of the process. Obstructing nominees through delay is used by members of Judiciary Committee and the full Senate to demonstrate that the concerns raised by interested groups are being heard (Bell 2002a, Scherer 2005). Other factors, such as the electoral timing variables, affect the two parts of the confirmation process differently. Nominees forwarded later in the president's term were subjected to more delay at the hands of the Senate Judiciary Committee in each model associated with delay at that stage. However, at the full Senate stage, this electoral timing variable had a more complicated and less consistent influence on delay. The president's ideological relationship to the Senate also had a varied effect at the distinct stages of the confirmation process. At the committee stage, nominees tended to be treated less favorably when the president's relationship to the relevant senator was less friendly. At the full Senate stage, there was no consistent relationship between the president's ideological proximity to the key senator and the treatment of that president's nominees.

Our approach of considering the distinct phases of the confirmation process has also allowed us to analyze how the committee's treatment of a nominee may affect that nominee's prospects before the full Senate. At least in the post-Bork era, a nominee's delay at the hands of the Judiciary Committee served to increase the delay that nominee would experience before the full Senate, independent of other factors that tend to increase full Senate delay, such as the presence of interest group opposition. In other words, committee delay of judicial nominees in and of itself begets further delay at the hands of the full Senate, indicating that the cue has been picked up "that what the committee wants is in the chamber's best interest” (Krehbiel 1991, 256). We detected no such influence of committee delay on full Senate treatment of nominees in the less contentious pre-Bork years.

Examining the distinct phases of the confirmation process also allows us to shift some attention away from the behavior of those on the Senate Judiciary Committee. Although previous research found that the bulk of delay in the confirmation process was attributable to the handling of nominees by the Judiciary Committee (Goldman 2003), considering delay at the Senate vote stage is also important. Slotnick and Goldman (1998) first identified the trend that delay at the full Senate vote stage had increased in the 104th Congress. They initially attributed this increase to Senator Dole's presidential election bid in 1996. Our findings indicate that the length of time nominees waited for Senate confirmation after being reported out of committee has been influenced by a host of political, electoral, and nomineespecific factors throughout the time period of our study, rather than in 
response to one presidential election bid. Furthermore, the vast majority (97.8\%) of nominees in our study who were reported out of committee were eventually confirmed by the full Senate, indicating that post-committee delay is not a particularly effective tool for killing a nomination. Although post-committee delay may be successful in defeating a small handful of nominees (including William Haynes, William Myers, and Terrence Boyle), it appears as though it is more consistently successful in achieving other purposes, such as signaling to interested observers that a problematic nominee is not being given rubber stamp approval by the full Senate.

Lastly, by distinguishing between the distinct phases of the confirmation process, we were able to examine how legislative signaling theory operates in the judicial confirmation process. Delay at the committee stage is somewhat effective as a tool to defeat nominees, given that 216 of the 251 defeated nominees in our analysis were "killed" at the committee stage. However, our findings also indicate that with respect to post-Bork district and circuit court nominees, Judiciary Committee delay influences full Senate vote delay. These findings provide some support for the theory that the committee signals the full Senate with respect to judicial nominees, and that these signals are picked up by those in the full Senate. We expected Judiciary Committee behavior to be especially influential when considering nominees to the district courts because of their lesser salience and greater number. However, we found that committee delay also influenced Senate vote delay for circuit court nominees specifically, indicating that the full Senate is also likely to pick up on committee delay of more important nominees to the circuit courts, at least in the post-Bork era of increased contention.

Our analysis has provided important new insights into the judicial confirmation process and the behavior of those involved in the two distinct phases of that process. This analysis helps us understand better how those involved in each stage of the highly politicized modern confirmation process utilize delay in the hopes of defeating nominees, but supports the theory that delay is used to signal others involved in the process as well. Those in the Senate pick up on signals sent by those on the committee, and those at both stages in the process use delay in response to objections raised by interested observers and in response to a president weakened by electoral politics. Given that modern judicial confirmation politics encourage all members of the Senate - even those in the minority and those not on the Judiciary Committee - to become more publicly involved in confirmation politics (Bell 2002a; Scherer 2005), we should expect delay to continue to be used both in the hopes of killing certain nominees, but also to signal others interested and involved in all aspects of the confirmation process. 


\section{NOTES}

${ }^{1}$ Some of the commonly-used delay tactics are the withholding of (or a negative response to) a blue slip by a home state senator, the use of an anonymous hold, and threat of a filibuster. See Bell 2002a for further discussion of these delay tactics.

${ }^{2}$ Other potentially useful signals may come in the form of the committee vote on a nominee, or the withholding of a blue slip by the home state senator. However, role call votes on lower court nominations have not been recorded until recently (Binder and Maltzman 2002; Epstein and Segal 2005). Similarly, most nominations that proceed to the full Senate do so without a recorded vote of the Judiciary Committee. The status of blue slips submitted for individual nominees, furthermore, has not consistently been made public. The Office of Legal Policy website, for example, provides blue slip status for nominees forwarded in the 107th and 108th Congresses, but not for those forwarded since then. Given Epstein and Segal's (2005:88) conclusion that the Judiciary Committee's action or non-action on lower court nominees has a particularly strong influence with the Senate, then, committee delay of nominees is a useful signal to examine for this analysis.

${ }^{3}$ We considered using both the divided government measure and the ideological distance measure in each model, but high collinearity concerns prevented us from including both variables in the models. While contemplating using a divided government measure, we also accounted for two party unity variables (majority and minority) and their interactions with the divided government measure similarly as Basinger and Mak (2010) did, but those models were problematic due to high collinearity between the two party unity variables.

${ }^{4}$ For example, President Bush publicly touted the high quality of many of his nominees, including Supreme Court nominee Samuel Alito and lower court nominees including Priscilla Owen, Terry Boyle, Bob Conrad, and Jim Denver by noting their ABA ratings (see President Bush's Radio Address of January 28, 2006, his Statement Calling for Prompt Senate Consideration of Judicial Nominees of May 9, 2005, and Remarks Following a Meeting with Judicial Nominees on July 7, 2004, all collected from Government Printing Office Federal Digital System at http://www.gpo.gov/fdsys/).

${ }^{5}$ Following Martinek et al. (2002), we excluded nominees from Guam, the Northern Mariana Islands, and the Virgin Islands. In addition, given its status as a specialized court (Carp et al. 2004), we excluded nominations made to the U.S Court of Appeals for the Federal Circuit.

${ }^{6}$ This coding rationale is similar to that of Bell (2002b), who argued that nominees could still be withdrawn over the course of a Senate recess. In addition, returning a nominee over the course of a Senate recess has become a routine part of the delay process in the Senate with unsuccessful nominees often being referred again by the president once the Senate reconvenes (Holmes and Savchak 2003).

${ }^{7}$ In order to include cases where the nominee was confirmed on the same day as being reported out of committee, we re-coded all such cases as being confirmed the next day. The stcox command in Stata does not allow a case to enter and exit the analysis at the same time (see Binder and Maltzman 2004).

${ }^{8}$ Developed by Keith T. Poole and Howard Rosenthal, DW-NOMINATE scores are estimates of legislators' positions using scaling techniques. With these scores, one can compare the ideological positions of members of different Congresses over time. Using the most recently-updated 2011 scores, we used first-dimension DW-NOMINATE scores, which primarily reflect disagreements about the role of the federal government, 
especially in economic matters (see http://www.voteview.com/dwnomin.htm). In their analysis of different pivot points in the federal judicial selection process, Primo et al. (2008) conclude that second-dimension scores (which tap into views on racial and social issues) are empirically inconsequential for most nominees since 1975. We therefore rely solely on the first-dimension in our analysis.

${ }^{9}$ In May of 2001, President Bush nominated a handful of individuals to the circuit and district courts. Within a month, Senator James Jeffords' (I-VT) defection from the Republican party converted control of the Senate to the Democrats, with Patrick Leahy (D-VT) taking over as chair of the Judiciary Committee. Given that nearly all of these nominees were soon returned to the president, only to be re-nominated by the president to the Democratically-controlled Senate (Holmes and Savchak 2003), the presidentcommittee chair distance variable for the nominees initially referred in May of 2001 was coded as the ideological distance between President Bush and Committee Chair Leahy.

${ }^{10}$ In choosing to use a dichotomous variable of interest group opposition to a nomination, we followed the rationale of Scherer et al. (2008), who argued that interest groups tend to work in coalitions when deciding whether or not to challenge a lower court nomination. As such, most nominees attract either no opposition or substantial opposition from interested groups.

${ }^{11}$ As did Martinek et al. (2002), we coded racial and ethnic minorities as those identified as African-American, Asian-American, Hispanic, Native American, or ArabAmerican.

${ }^{12}$ To test for the proportional hazards assumption, we graphed and analyzed Schoenfeld residuals using the estat phtest command in Stata 11.2.

\section{REFERENCES}

Allison, Garland W. 1996. Delay in the Senate Confirmation of Federal Court Nominees. Judicature 80:8-15.

Basinger, Scott, and Maxwell Mak. 2010. The Changing Politics of Federal Judicial Nominations. Congress and the Presidency 37:157-175.

Bell, Lauren Cohen. 2002a. Warring Factions: Interest Groups, Money, and the New Politics of Senate Confirmation. Columbus: The Ohio State University Press.

Bell, Lauren Cohen. 2002b. Senatorial Discourtesy: The Senate's Use of Delay to Shape the Federal Judiciary. Political Research Quarterly 55:589-607.

Binder, Sarah A. 1999. The Dynamics of Legislative Gridlock, 1947-1996. American Political Science Review 93:519-533.

Binder, Sarah A., and Forrest Maltzman. 2002. Senatorial Delay in Confirming Judges, 1947-1998. American Journal of Political Science 46:190-199.

Binder, Sarah A., and Forrest Maltzman. 2004. The Limits of Senatorial Courtesy. Legislative Studies Quarterly 29:5-22.

Binder, Sarah A., and Forrest Maltzman. 2009. Advice and Dissent: The Struggle to Shape the Federal Judiciary. Washington, DC: Brookings Institution Press.

Box-Steffensmeier, Janet M., and Bradford S. Jones. 2004. Event History Modeling. Cambridge: Cambridge University Press.

Carp, Robert A., Ronald Stidham, and Kenneth L. Manning. 2004. Judicial Process in America, 6th ed. Washington, DC: CQ Press.

Chase, Harold. 1972. Federal Judges: The Appointing Process. Minneapolis: University of Minnesota Press. 
Epstein, Lee, and Jeffrey A. Segal. 2005. Advice and Consent: The Politics of Judicial Appointments. New York: Oxford University Press.

Epstein, Lee, Rene Lindstadt, Jeffrey A. Segal, and Chad Westerland. 2006. The Changing Dynamics of Senate Voting on Supreme Court Nominees. Journal of Politics 68:296-307.

Ferejohn, John A., and Charles R. Shipan. 1989. Congressional Influence on Administrative Agencies: A Case Study of Telecommunications Policy. In Congress Reconsidered, 4th ed., eds. Lawrence C. Dodd and Bruce I. Oppenheimer. Washington, DC: CQ Press.

Goldman, Sheldon. 1997. Picking Federal Judges: Lower Court Selection from Roosevelt Through Reagan. New Haven, CT: Yale University Press.

Goldman, Sheldon. 2003. Assessing the Senate Judicial Confirmation Process: The Index of Obstruction and Delay. Judicature 86:251-257.

Goldman, Sheldon, and Elliot Slotnick. 1999. Clinton's Second Term Judiciary: Picking Judges under Fire. Judicature 82:264-283.

Goldman, Sheldon, Elliot Slotnick, Gerard Gryski, and Sara Schiavoni. 2005. W. Bush's Judiciary: The First Term Record. Judicature 88:244-275.

Goldman, Sheldon, Elliot Slotnick, and Sara Schiavoni. 2011. Obama’s Judiciary at Midterm: The Confirmation Drama Continues. Judicature 94:262-303.

Hartley, Roger E. 2001. Senate Delay of Minority Judicial Nominees: A Look at Race, Gender, and Experience. Judicature 84:190-197.

Hartley, Roger E., and Lisa M. Holmes. 1997. Increasing Senate Scrutiny of Lower Federal Court Nominees. Judicature 80:274-78.

Hartley, Roger E., and Lisa M. Holmes. 2002. The Increasing Scrutiny of Lower Federal Court Nominees. Political Science Quarterly 117:259-278.

Holmes, Lisa M. 2007. Presidential Strategy in the Judicial Appointment Process: 'Going Public' in Support of Nominees to the U.S. Courts of Appeals. American Politics Research 35:567-594.

Holmes, Lisa M., and Elisha Savchak. 2003. Judicial Appointment Politics in the 107th Congress. Judicature 86:232-239.

Johnson, Timothy R., and Jason M. Roberts. 2004. Presidential Capital and the Supreme Court Confirmation Process. The Journal of Politics 66:663-683.

Johnson, Timothy R., and Jason M. Roberts. 2005. Pivotal Politics, Presidential Capital, and Supreme Court Nominations. Congress and the Presidency 32:31-48.

Kingdon, John. 1973. Congressmen's Voting Decisions. New York: Harper and Row.

Krehbiel, Keith. 1991. Information and Legislative Organization. Ann Arbor: University of Michigan Press.

Krehbiel, Keith. 1998. Pivotal Politics: A Theory of U.S. Lawmaking. Chicago: University of Chicago Press.

Martinek, Wendy L., Mark Kemper, and Steven R. Van Winkle. 2002. To Advise and Consent: The Senate and Lower Federal Court Nominations, 1977-2002. Journal of Politics 64:337-361.

Massie, Tajuana, Thomas G. Hansford, and Donald R. Songer. 2004. The Timing of Presidential Nominees to the Lower Federal Courts. Political Research Quarterly 57:145-154.

Moraski, Bryon J., and Charles R. Shipan. 1999. The Politics of Supreme Court Nominations: A Theory of Institutional Constraints and Choices. American Journal of Political Science 43:1069-1095.

Morrow, William L. 1969. Congressional Committees. New York: Charles Scribner's Sons. 
Nixon, David C., and David L. Goss. 2001. Confirmation Delay for Vacancies on the Circuit Courts of Appeals. American Politics Research 29:246-274.

Poole, Keith, and Howard Rosenthal. 1997. Congress: A Political-Economic History of Roll Call Voting. New York: Oxford University Press.

Primo, David M., Sarah A. Binder, and Forrest Maltsman. 2008. Who Consents? Competing Pivots in Federal Judicial Selection. American Journal of Political Science 52:471-489.

Ruckman, P.S. 1993. The Supreme Court, Critical Nominations, and the Senate Confirmation Process. Journal of Politics 55:793-805.

Scherer, Nancy. 2005. Scoring Points: Politicians, Activists, and the Lower Federal Court Appointment Process. Palo Alto, CA: Stanford University Press.

Scherer, Nancy, Brandon L. Bartels, and Amy Steigerwalt. 2008. Sounding the Fire Alarm: The Role of Interest Groups in the Lower Federal Court Confirmation Process. The Journal of Politics 70:1026-1039.

Shipan, Charles, and Megan L. Shannon. 2003. Delaying Justice(s): A Duration Analysis of Supreme Court Confirmations. American Journal of Political Science 47:654668.

Slotnick, Elliot E., and Sheldon Goldman. 1998. Congress and the Courts: A Case of Casting. In Great Theatre: The American Congress in the 1990s, eds. Herbert F. Weisberg and Samuel C. Patterson. New York: Cambridge University Press.

Sollenberger, Mitchel A. 2010. The Blue Slip: A Theory of Unified and Divided Government, 1979-2009. Congress and the Presidency 37:125-156.

Solowiej, Lisa A., Wendy L. Martinek, and Thomas L. Brunnell. 2005. Partisan Politics: The Impact of Party in the Confirmation of Minority and Female Federal Court Nominees. Party Politics 11:557-577.

Stratmann, Thomas, and Jared Garner. 2004. Judicial Selection: Politics, Biases, and Constituency Demands. Public Choice 118:251-270. 